\title{
Opportunistic Disease or Metastatic Lesions: A Rare Finding in a Patient with Bladder Cancer
}

\author{
Michael Simon ${ }^{\mathrm{a}} \quad$ Natalie Elkayam $^{\mathrm{a}} \quad$ Jonathan Smerling ${ }^{\mathrm{b}}$ \\ Michael Marcelin ${ }^{\mathrm{a}, \mathrm{b}} \quad$ Stephan Kamholza,b \\ aDepartment of Medicine, Maimonides Medical Center; 'bSUNY Downstate College of Medicine, New York, NY, USA
}

\section{Key Words}

Bladder cancer • Brain metastases • Opportunistic infection • Ring-enhancing lesion

\begin{abstract}
A 66-year-old male with a history of human immunodeficiency virus infection and metastatic bladder cancer presented to our hospital for a further workup of a focal seizure involving the patients left upper extremity. The patient was undergoing active chemotherapy at the time of admission and had a CD4 count of 111. Magnetic resonance imaging of the brain revealed multiple ring-enhancing lesions in the right frontal lobe associated with vasogenic edema, and mass effect at the right frontal horn of the lateral ventricles. As the imaging was not consistent with typical metastatic disease of the bladder, further testing was performed. A lumbar puncture was performed to assist in differentiating between malignant and infectious causes in the setting of a low CD4 count. The cerebral spinal fluid was sterile and no malignant cells were identified. Protein and glucose levels of
\end{abstract}

\section{KARGER}

Fax +4161306 1234

E-Mail karger@karger.com

www.karger.com
(C) 2019 The Author(s)

Published by S. Karger AG, Basel Upen access

This article is licensed under the Creative Commons AttributionNonCommercial-NoDerivatives 4.0 International License (CC BYNC-ND) (http://www.karger.com/Services/OpenAccessLicense). NC-ND) (http://www.karger.com/Services/OpenAccessLicense)
Usage and distribution for commercial purposes as well as any distribution of modified material requires written permission. the cerebral spinal fluid were within normal range. To confirm the presence of metastatic disease, a brain biopsy was performed and found to be consistent with metastatic carcinoma with a bladder primary. The patient subsequently underwent radiation therapy to the site of the brain metastasis.

C 2019 The Author(s)

Published by S. Karger AG, Basel

\section{Introduction}

Bladder cancer is the sixth most common cancer in the United States, with the most common subtype being papillary transitional cell carcinoma $[1,2]$. Common sites of metastasis include the lymph nodes, liver, lung, bone and peritoneum [3, 4]. Central nervous system (CNS) metastases are rare, with report incidence ranging from 0 to 7\% [5-8]. We present a case of a patient with acquired immune deficiency syndrome (AIDS) and urothelial carcinoma of the bladder with ring-enhancing lesions in the brain. 


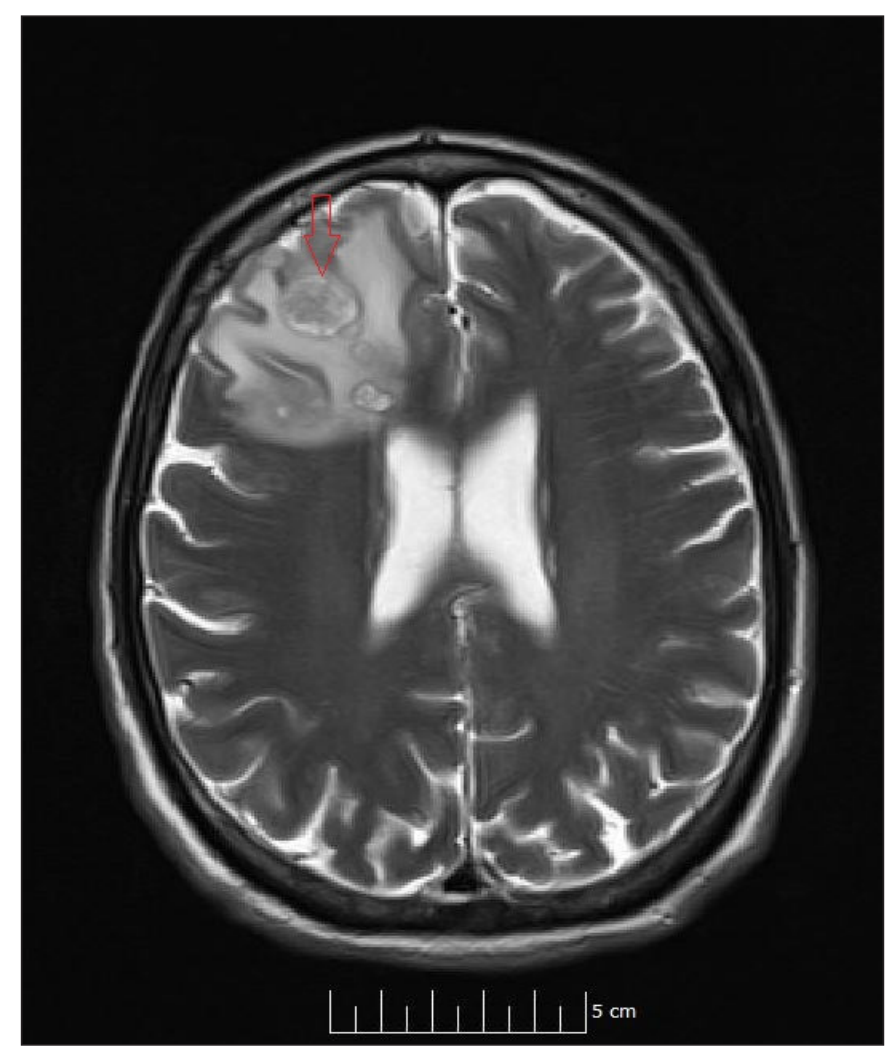

Fig. 1. Axial T2-weighted image of the brain with multiple ring-enhancing lesions at the right frontal lobe with surrounding edema. Arrow is pointing to one such lesion.

\section{Case Report}

A 66-year-old man presented to our hospital with a new onset focal partial seizure of his right upper extremity. His past medical history included human immunodeficiency virus (HIV) infection on highly active antiretroviral therapy (HAART) hypertension, coronary artery disease, obstructive sleep apnea and metastatic high-grade urothelial carcinoma of the bladder involving the lungs and bones. The patient had previously received neoadjuvant chemotherapy and pelvic radiation for locally advanced bladder cancer, with complete remission of his disease. He was recently found to have disease recurrence with lung metastases and was restarted on chemotherapy. The disease continued to progress with new metastases to the bones, including right ankle and sternal manubrium and left scapula. While undergoing palliative radiotherapy to these sites, the patient was found to be suffering from a right focal partial seizure in his right arm.

The patient had never had seizures prior to this episode and was referred for a brain magnetic resonance imaging (MRI). The MRI demonstrated multiple ring-enhancing lesions in the right frontal lobe and right parietal lobe, accompanied by vasogenic edema in the same areas (fig. 1). The appearance of the lesions was not consistent with typical metastatic lesions, and in view of the patient's history of HIV there was concern for an infectious etiology. The patient was started on dexamethasone because of vasogenic cerebral edema and his HAART therapy was continued.

On presentation, the patient was afebrile with vital signs within normal limits. Pertinent laboratory data included creatinine $1.9 \mathrm{mg} / \mathrm{dl}$ (unchanged), calcium $11.1 \mathrm{mg} / \mathrm{dl}$, albumin $2.6 \mathrm{~g} / \mathrm{dl}$, hemoglobin of $10.2 \mathrm{gm} / \mathrm{dl}$ and MCV $86 \mathrm{fL}, \mathrm{CD} 4$ count was 111/ $\mu \mathrm{l}$ and HIV viral load was undetectable.

The patient subsequently underwent a lumbar puncture and cerebral spinal fluid (CSF) analysis revealed total protein of 36 $\mathrm{mg} / \mathrm{dl}$, glucose $74 \mathrm{mg} / \mathrm{dl}$, and LDH $<25 \mathrm{U} / \mathrm{l}$. CSF was clear with 0 red blood cells and 3 white blood cells, all of which were lymphocytes. The CSF was negative for bacterial and fungal growth on cultures. Cryptococcal antigen was negative. Serum toxoplasmosis IgG was negative as was CSF cytology for malignant cells.

Due to the negative findings on CSF and atypical presentation on imaging, the patient underwent a right frontal lobe craniotomy with resection. Pathology was consistent with carcinoma with bladder primary.

The patient's clinical course was complicated by complaints of bladder incontinence. He underwent a lumbar and thoracic spine MRI, which showed L3/4 enhancement with mild disc space enhancement likely due to degenerative changes but without evidence of infiltrative disease.

The patient underwent palliative whole brain radiation. He was not considered to be a candidate for stereotactic radiosurgery due to multiplicity and clustering of lesions.

\section{Discussion}

This patient with bladder cancer and HIV presented with a focal seizure. MRI revealed multiple CNS ring-enhancing lesions. The differential diagnosis included opportunistic infection and metastatic disease. The diagnosis of metastatic bladder cancer was confirmed histologically.

Bladder cancer is known to metastasize to multiple sites of the body but rarely to the brain. When it does metastasize to the brain the prognosis is poor with median survival of 2-4 months despite treatment $[8,9]$. In our patient with bladder cancer, ring-enhancing lesions were not clearly due to metastatic disease as it was confounded by a diagnosis of AIDS.

This patient had HIV/AIDS with a CD4 count of 111 and therefore there was a concern that the patient had developed an opportunistic infection. Typically patients present with opportunistic infections when their CD4 count falls below $\sim 100$. CNS infections complicating HIV include toxoplasmosis (by far the most common $\sim 50 \%$ of all brain lesions), primary CNS lymphoma, progressive multifocal leukoencephalopathy and focal HIV encephalopathy $[10,11]$. In this patient with both meta- 
static bladder cancer and AIDS, the origin remained unclear and required further investigation before treatment could be rendered.

Although the role of brain biopsy in guiding treatment for AIDS-associated brain lesions is controversial [12], obtaining a biopsy in the patient was necessary to confirm diagnosis and treat appropriately $[13,14]$. Due to an unclear origin of the brain ring-enhancing lesions, brain radiation therapy could not be performed until a diagnosis was confirmed. The main differential diagnoses due to the patient's immunocompromised state and previous radiation therapy included toxoplasmosis of the brain, primary CNS lymphoma or metastatic lesions. Only upon histology being consistent with bladder cancer was the patient able to undergo palliative radiation.

Several reports have highlighted the concurrence of HIV and bladder cancer $[15,16]$. The conclusions from these studies suggest that in the era of HAART therapy, HIV patients are living longer, thus allowing them to develop one of the more common cancers [1]. Often bladder cancer in these patients exhibits more aggressive clinical behavior.

\section{Conclusion}

We present a unique case of a patient with both bladder cancer and HIV, who presented with multiple brain ring-enhancing lesions. Treatment options were complicated pending biopsy, due to multiple differential diagnoses, including brain toxoplasmosis, primary CNS lymphoma or metastatic disease. After a thorough workup, a diagnosis of metastatic bladder cancer was made and the patient was able to undergo palliative radiation therapy. It is important for physicians to keep an open mind to many differential diagnoses even with a seemly simple one, to assure appropriate therapy and care be provided to a patient. As in our patient, a brain biopsy was necessary to assure the proper treatment.

\section{References}

1 Noone A, Howlader N, Krapcho M, Miller D, Brest A, Yu M, Ruhl J, Tatalovich Z, Mariotto A, Lewis DR, Chen HS, Feuer EJ, Cronin KA: SEER Cancer Statistics Review, 1975-2015. April 2018. https://seer.cancer. gov/csr/1975_2015/.

2 Zhang Y, Zhu C, Curado MP, Zheng T, Boyle $\mathrm{P}$ : Changing patterns of bladder cancer in the USA: evidence of heterogeneous disease. BJU Int 2012;109:52-56.

-3 Shinagare AB, Ramaiya NH, Jagannathan JP, Fennessy FM, Taplin ME, Van den Abbeele AD: Metastatic pattern of bladder cancer: correlation with the characteristics of the primary tumor. AJR Am J Roentgenol 2011;196:117-122.

4 Wallmeroth A, Wagner U, Moch H, Gasser TC, Sauter G, Mihatsch MJ: Patterns of metastasis in muscle-invasive bladder cancer (pT2-4): an autopsy study on 367 patients. Urol Int 1999;62:69-75.

5 Anderson RS, el-Mahdi AM, Kuban DA, Higgins EM: Brain metastases from transitional cell carcinoma of urinary bladder. Urology 1992;39:17-20.
6 Atmaca AF, Akbulut Z, Demirci A, Belenli O, Alici S, Balbay DM: Multiple subcutaneous nodular metastases from transitional cell carcinoma of the bladder. Pathol Oncol Res 2007;13:70-72.

7 Davis RP, Spigelman MK, Zappulla RA, Sacher M, Strauchen JA: Isolated central nervous system metastasis from transitional cell carcinoma of the bladder: report of a case and review of the literature. Neurosurgery 1986;18:622-624.

-8 Sarmiento JM, Wi MS, Piao Z, Stiner ES: Solitary cerebral metastasis from transitional cell carcinoma after a 14-year remission of urinary bladder cancer treated with gemcitabine: case report and literature review. Surg Neurol Int 2012;3:82.

-9 Mahmoud-Ahmed AS, Suh JH, Kupelian PA, Klein EA, Peereboom DM, Dreicer R, Barnett GH: Brain metastases from bladder carcinoma: presentation, treatment and survival. J Urol 2002; 167:2419-2422.

10 Ammassari A, Cingolani A, Pezzotti P, De Luca DA, Murri R, Giancola ML, Larocca LM, Antinori A: AIDS-related focal brain lesions in the era of highly active antiretroviral therapy. Neurology 2000;55:1194-1200.

11 Wiler JL: Diagnosis: toxoplasmosis with ring-enhancing brain lesions. Emerg Med News 2006;28(8):19.
12 Zibly Z, Levy I, Litchevski V, Nass D, Hofmann C, Barham J, Graves CA, Spiegelmann R, Hadani M, Cohen ZR: Brain biopsy in AIDS patients: diagnostic yield and treatment applications. AIDS Res Ther 2014;11:4.

13 Franzini A, Leocata F, Giorgi C, Allegranza A, Servello D, Broggi G: Role of stereotactic biopsy in multifocal brain lesions: considerations on 100 consecutive cases. J Neurol Neurosurg Psychiatry 1994;57:957-960.

14 Meshkini A, Shahzadi S, Alikhah H, Naghavi-Behzad M: Role of stereotactic biopsy in histological diagnosis of multiple brain lesions. Asian J Neurosurg 2013;8:69.

-15 Chawki S, Ploussard G, Montlahuc C, Verine J, Mongiat-Artus P, Desgrandchamps F, Molina JM: Bladder cancer in HIV-infected adults: an emerging issue? Case-reports and systematic review. PLoS ONE 2015; 10:e0144237.

16 Gaughan EM, Dezube BJ, Bower M, Aboulafia DM, Bohac G, Cooley TP, Pantanowitz L: HIV-associated bladder cancer: a case series evaluating difficulties in diagnosis and management. BMC Urol 2009;9:10. 